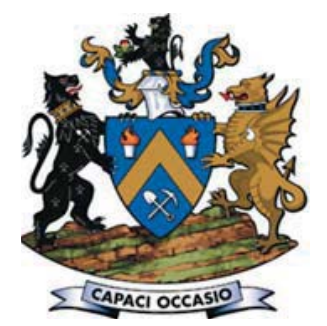

\title{
Synthesis of 3-hydroxy-2-naphthyl hydroxamic acid collector: flotation performance and adsorption mechanism on bastnaesite
}

\author{
by Z. Yang*, W. Wu*, and X. Bian*
}

\section{Synopsis}

The synthesis of 3-hydroxy-2-naphthyl hydroxamic acid (H205) as a collector for bastnaesite is described. The flotation performance of $\mathrm{H} 2 \mathrm{O} 5$ with respect to bastnaesite was investigated by flotation tests, measurements of the surface adsorption capacity, and polarizing microscopy. The results indicated that $\mathrm{H} 2 \mathrm{O} 5$ exhibits superior collecting performance compared with direct flotation recovery of bastnaesite, with recoveries above $90 \%$ at $\mathrm{pH} 8-9$. The adsorption mechanism of $\mathrm{H} 205$ on bastnaesite was studied by solution chemistry analysis and $\zeta$-potential tests. The results showed that the adsorption of $\mathrm{H} 2 \mathrm{O} 5$ is associated with the types and concentrations of hydrolysis products of rare earth cations on the bastnaesite surface. At pH 8-9, the hydrolysis-dominant components $\mathrm{RE}(\mathrm{OH})^{2+}$ and $\mathrm{RE}(\mathrm{OH})_{2}+$ of the rare earth cations were adsorbed onto the bastnaesite surfaces, which were considered to be the major positive active points and were beneficial to chemical adsorption of the reagents. The $\mathrm{pH}$ range of $7-10$ was optimum for bastnaesite floatability, and the adsorption of $\mathrm{H} 205$ on bastnaesite was by means of chemical adsorption through formation of a five-membered ring chelate.

\section{Keywords}

3-hydroxyl-2-naphthyl hydroxamic acid (H205), flotation, bastnaesite, chemical adsorption.

\section{Introduction}

The rare earth elements (REEs) have long been known as 'industrial gold' and are widely used in the petroleum, chemical, ceramic, metallurgical, and permanent magnet material industries because of their special physicochemical properties (Chen, 2011; Krishnamurthy and Guptac, 2002; Esquivel, Bohe, and Pasquevich, 2002; Abrahami, Xiao, and Yang, 2015). Demand for REEs is growing in response to continuous advances in science and technology. Currently, most REEs are extracted from bastnaesite ((Ce,La) $\left.\mathrm{CO}_{3} \mathrm{~F}\right)$ (Chelgani et al., 2015; Yosry, 1990), which is recovered from rare earth ores by flotation. Typically, hydroxamic acids are used as bastnaesite collectors (Xu, 2015; Ren, 1997; Mousumi and Venugopal, 2016). Research into the mechanism of interaction between hydroxamic acids and bastnaesite is important for improving the recoveries of bastnaesite. However, there have been few studies that examine this mechanism.

Compared to other available collectors, hydroxamic acid has been shown to have better selectivity for bastnaesite. Hydroxamic acids (R-CO-NHOH) are much weaker acids than the corresponding carboxylic acids with identical carbon chains (Jiang et al., 2010; Buglyo et al., 2007; Wu and $\mathrm{Zhu}, 2006$; Herrera, 2003). However, hydroxamic acids are better at selecting chelating metal ions (Wang, Liu, and Miller, 2008; Griffith et al., 2011). The two 0 atoms in the carbonyl and hydroxyl groups of a hydroxamate molecule bond with a metal cation to form a fivemembered ring structure (Chelgani et al., 2015). Researchers have reported on the surface complexes of hydroxamic acid and metal species on the mineral surfaces (Jiang et al., 2010; $\mathrm{Wu}$ and $\mathrm{Zhu}, 2006)$. This research has led to the wide use of hydroxamic acids such as octyl hydroxamic acid and salicylhydroxamic acid as collectors for flotation recovery of metal oxide minerals, including copper (Lee, 1998), tin (Sreenivas and Padmanabhan, 2002) and rare earth minerals (Zhou et al., 2015a; Jordens et al., 2014).

Flotation is a complex physical and chemical process in which collectors play a decisive role. Flotation is a useful approach for fine-grained rare earth occurrences. Other physical separation methods (e.g. magnetic, gravity) have been proven to be impractical. There have been a number of investigations of flotation processes for bastnasite ores (Cai et al., 2009). In each case conditions, including a suitable collector and $\mathrm{pH}$, have been established for the flotation of the desired minerals and depression of unwanted minerals.

In our study, we used H205, which was synthesized in a laboratory, as a hydroxamic acid rare earth collector. We investigated the effects of H205 dosage and the flotation pH on pure bastnasite. Further, we studied the collecting property and adsorption mechanism of $\mathrm{H} 205$ on the surface of bastnasite.

* School of Metallurgy, Northeastern University, Shenyang 110819, Liaoning,China.

(C) The Southern African Institute of Mining and Metallurgy, 2017. ISSN 2225-6253. Paper received oct. 2016; revised paper received Apr. 2017. 


\section{Synthesis of 3-hydroxy-2-naphthyl hydroxamic acid collector}

\section{Materials and methods}

\section{Materials}

\section{Minerals}

Hand-picked, high-purity bastnaesite was obtained from Baotou, Mongolia, China, and ground using a porcelain mill. The ground samples were wet-sieved to separate the particles that were less than $74 \mu \mathrm{m}$ for flotation tests. A portion of this fraction was further ground in an agate mortar to obtain particles less than $5 \mu \mathrm{m}$ for the zeta potential measurements.

\section{Reagents}

Analytical-grade $\mathrm{HCl}$ and $\mathrm{NaOH}$ were used as $\mathrm{pH}$ modifiers. Analytical-grade 3-hydroxy-2-naphthyl methyl acid, $\mathrm{NH}_{2} \mathrm{OH} \cdot \mathrm{HCl}$, methanol, and $\mathrm{H}_{2} \mathrm{SO}_{4}$ were used to synthesize the collector. Distilled water with a pH of 6 to 7 was used to prepare all reagent solutions and for the flotation tests. Pine oil provided by Baogang Corporation (Inner Mongolia, China)was used as a frother. The 3-hydroxy-2-naphthyl hydroxamic acid collector was synthesized in the laboratory using the following method.

> Synthesis of 3-hydroxy-2-naphthyl methyl acid methyl ester-3-hydroxy-2-naphthyl methyl acid $(1 ; 18.8 \mathrm{~g}$, $0.1 \mathrm{~mol})$ was reacted with methanol $(16.0 \mathrm{~g}, 0.5 \mathrm{~mol})$ in the presence of concentrated sulphuric acid $(0.76$ $\mathrm{mL}, 0.014 \mathrm{~mol}$ ) at $65^{\circ} \mathrm{C}$ for 6 hours. The unreacted methanol was then removed under reduced pressure and 3-hydroxy-2-naphthyl acid methyl ester (2; 17.3 g) was obtained with $85.2 \%$ yield.

> Synthesis of 3-hydroxy-2-naphthyl hydroxamic acidSodium hydroxide $(8.8 \mathrm{~g}, 0.2 \mathrm{~mol})$ and hydroxylamine hydrochloride $(7.64 \mathrm{~g}, 0.1 \mathrm{~mol}$ ) were dissolved in water (50 mL). Within 0.5 hours, 3-hydroxy-2-naphthyl acid methyl ester $(2 ; 20.3 \mathrm{~g}, 0.1 \mathrm{~mol}$, dissolved in $60 \mathrm{~mL}$ methanol) was added at $50^{\circ} \mathrm{C}$. The mixture was stirred for 8 hours at $50^{\circ} \mathrm{C}$, then methanol was removed from the reaction mixture under reduced pressure, the residue was acidized with $3 \mathrm{~mol} / \mathrm{L} \mathrm{HCl}$, and 3-hydroxy2-naphthyl hydroxamic acid $(3 ; 16.4 \mathrm{~g})$ was obtained with $71.2 \%$ yield.

The synthesis route is shown schematically in Figure 1.

\section{Experimental}

\section{Flotation tests}

Flotation tests were carried out using an XFD-0.1L flotation machine (mechanical agitation) with a $100 \mathrm{~mL}$ plexiglass cell. The impeller speed was fixed at $1500 \mathrm{r} / \mathrm{min}$. The $\mathrm{pH}$ values of the pulp were measured by a PHS-3E pH meter. All the flotation tests were carried out at $25^{\circ} \mathrm{C}$. For each test, $20.0 \mathrm{~g}$ mineral samples were placed in the cell with $100 \mathrm{~mL}$ distilled water at $25^{\circ} \mathrm{C}$. After adding the required amount of collector

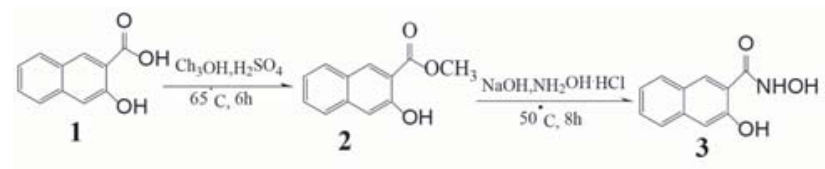

Figure 1-Synthesis route for 3-hydroxy-2-naphthyl hydroxamic acid
(H205), the pulp was agitated for 2 minutes and the pH was then adjusted to a designated value with hydrochloric acid or sodium hydroxide solution before flotation. Flotation was conducted for 5 minutes. The concentrates and tailings were weighed after filtration and drying, respectively.

\section{Zeta potential tests}

The zeta potential tests were carried out using a JS94H electrophoresis apparatus (Beckman Coulter Inc., USA). $100 \mathrm{mg}$ of $-5 \mu \mathrm{m}$ mineral samples were added to $40 \mathrm{~mL}$ of aqueous solution with or without $0.6 \mathrm{~g} / \mathrm{L} \mathrm{H} 205$, and then stirred for 15 minutes. The $\mathrm{pH}$ values were adjusted using $\mathrm{HCl}$ or $\mathrm{NaOH}$ solutions. Each sample was measured five times independently, and the average value was taken. For $\mathrm{pH}$ measurements, the samples were allowed to equilibrate for 5 minutes before measurement. To avoid zeta potential hysteresis, fresh samples were prepared for acidic and basic zeta potential measurements at $25^{\circ} \mathrm{C}$.

\section{Adsorption of $\mathrm{H} 205$ on the mineral surface}

The $\mathrm{H} 205$ concentration in the aqueous solutions was measured by a UV-V double-beam UV-2100 spectrophotometer from Labtech Co. (China). Bastnaesite samples $(1.0 \mathrm{~g})$ with $0.6 \mathrm{~g} / \mathrm{L}$ of $\mathrm{H} 205$ were measured at different $\mathrm{pH}$ values. The residual concentration of the surface collector solution was measured and then converted to the amount of $\mathrm{H} 205$ adsorbed on the bastnaesite surfaces. The samples were stirred for 5 minutes at $25^{\circ} \mathrm{C}$, at a certain $\mathrm{pH}$ value, and then filtered and the residual concentration of H205 in the filtrate measured.

\section{Results and discussion}

\section{Flotation results}

Figure 2 showed the relationship between the recovery of bastnaesite and $\mathrm{H} 2 \mathrm{O} 5$ dosage when the $\mathrm{pH}$ was adjusted to 8 using sodium hydroxide. The recovery increased with increasing $\mathrm{H} 2 \mathrm{O} 5$ concentration, reaching a maximum of about $96 \%$ at an $\mathrm{H} 205$ dosage of $0.6 \mathrm{~g} / \mathrm{L}$. This demonstrates that bastnaesite has good floatability in the $\mathrm{H} 2 \mathrm{O} 5$ flotation system.

Figure 3 shows the effect of $\mathrm{pH}$ on bastnaesite recovery at an $\mathrm{H} 2 \mathrm{O} 5$ dosage of $0.6 \mathrm{~g} / \mathrm{L}$. At pH values of $7-10$, the bastnaesite retained relatively good floatability and the recovery rates were all above $80 \%$.

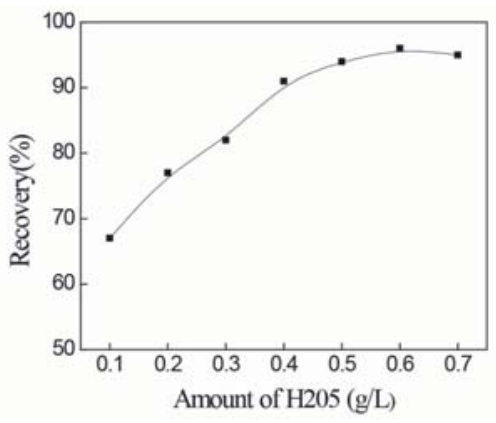

Figure 2-Relationship between floatability of bastnaesite and $\mathrm{H} 2 \mathrm{O} 5$ dosage, at $\mathrm{pH} 8$ 


\section{Synthesis of 3-hydroxy-2-naphthyl hydroxamic acid collector}

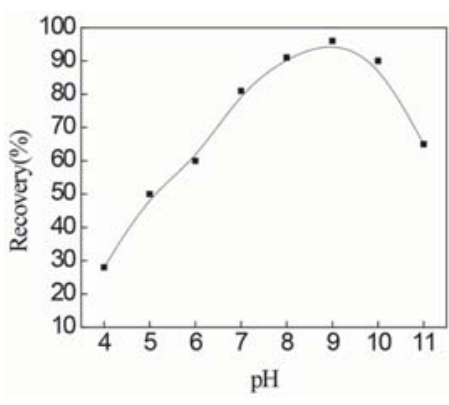

Figure 3-Effect of pH on the floatability of bastnaesite at $0.6 \mathrm{~g} / \mathrm{L} \mathrm{H} 2 \mathrm{O} 5$

\section{Polarizing microscopy}

Figures 4-6 show images of bastnaesite flotation froth at an $\mathrm{H} 205$ dosage of $0.6 \mathrm{~g} / \mathrm{L}$ and at $\mathrm{pH}$ values of 2, 8, and 13, respectively. It can be seen that many bastnaesite particles adhered to the bubble surfaces at $\mathrm{pH} 8$, whereas the particles did not adhere to the bubble surfaces at pH 2 and $\mathrm{pH} 13$.

\section{Amount of $\mathrm{H} 2 \mathrm{O} 5$ adsorption on bastnaesite surfaces}

Figure 7 shows the effect of pH on the adsorption of $\mathrm{H} 2 \mathrm{O} 5$ on the bastnaesite surfaces at an initial collector concentration of $0.6 \mathrm{~g} / \mathrm{L}$. At $\mathrm{pH} 2$, adsorption of $\mathrm{H} 2 \mathrm{O} 5$ was approximately zero. With increasing $\mathrm{pH}$ the adsorption rose sharply, reaching a maximum at $\mathrm{pH} 8$, and then decreasing sharply to approximately zero at $\mathrm{pH} 12$. Thus, it can be seen that the preferable $\mathrm{pH}$ range for $\mathrm{H} 2 \mathrm{O} 5$ adsorption on the bastnaesite surfaces is 7 to 9 , which is in accordance with the results of the flotation tests.

\section{Solution chemistry analysis of the flotation process}

$\mathrm{H} 2 \mathrm{O} 5$ is a very weak acid - even weaker than carbonic acid (Xu, Xu, and Wang, 2002; Chi and Wang, 2014). According to the soft and hard acid-alkaline (HSAB) theory (Xu, Xu, and Wang, 2006), hydroxamic acid forms relatively unstable chelates with alkali metals, alkaline earth metals, and other ions. However, it forms relatively stable chelates with transition metals such as the REEs, iron, copper, and other hard acid metal ions. In these chelates, the chemical bonds between the metal ions and the hydroxamic acid are substantially coordinate-covalent bonds (Che et al., 2004a, 2004b). The crystal surface characteristics of the minerals are closely associated with the floatability. The hydroxamic acid and lattice ions on the surfaces of the rare earth minerals are formed into a complex with a coordinate-covalent bond. This complex is strongly hydrophobic, and renders the minerals floatable when the mineral surfaces are covered. The chelate formed by the complex and the alkali metals or alkaline-earth metals and other ions is of an ionic type and is weakly hydrophobic, and therefore has relatively poor floatability in hydroxamic acid systems (Fuerstenau, 1985; Jordens, Chen, and Waters, 2013; O'Brien et al., 1997; Sreenivas and Padmanabhan, 2002). According to this principle, using $\mathrm{H} 205$ as the collector, a rare earth concentrate suitable for further processing (above 50\% rare earth oxides) can be obtained from complex rare earth ores by flotation.

In the flotation pulp system the conditions for interaction between the flotation reagents and the minerals are determined by the dissolution of the minerals, dissociation

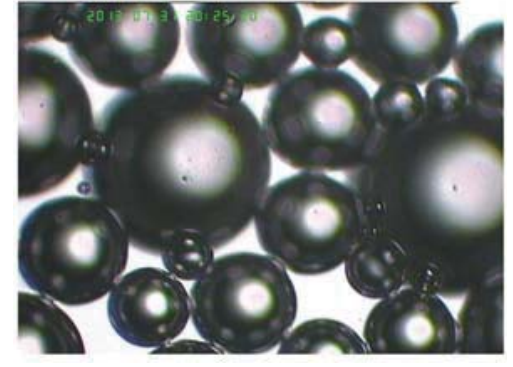

Figure 4-Bastnaesite flotation froth at $\mathrm{pH} 2, \mathrm{H} 205$ dosage $0.6 \mathrm{~g} / \mathrm{L}$

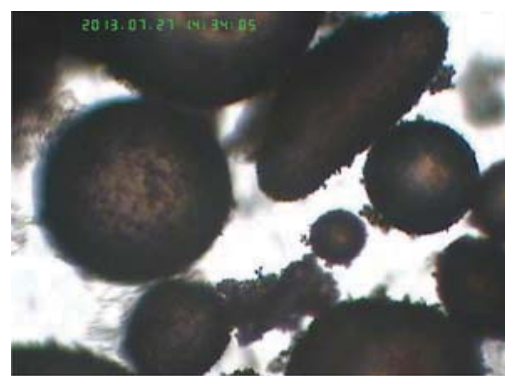

Figure 5-Bastnaesite flotation froth at $\mathrm{pH} 8, \mathrm{H} 205$ dosage $0.6 \mathrm{~g} / \mathrm{L}$

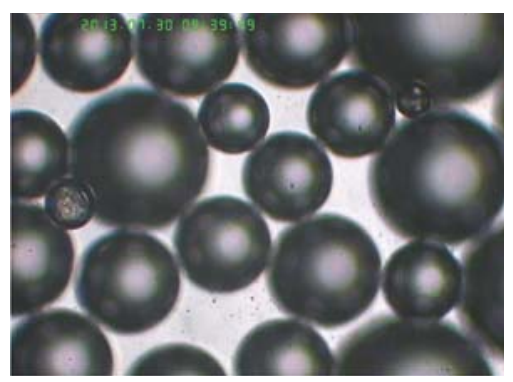

Figure 6-Bastnaesite flotation froth at pH 13, H205 dosage $0.6 \mathrm{~g} / \mathrm{L}$

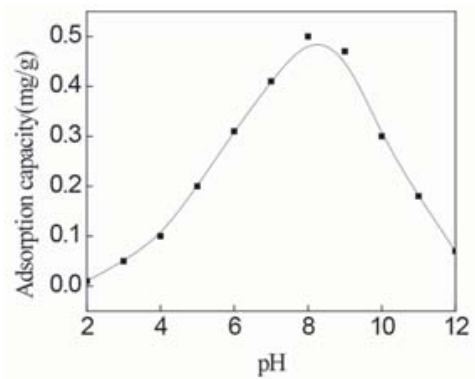

Figure 7-Effect of $\mathrm{pH}$ value on the adsorption of $\mathrm{H} 2 \mathrm{O} 5$ on the bastnaesite surfaces at $\mathrm{H} 2 \mathrm{O} 5$ dosage of $0.6 \mathrm{~g} / \mathrm{L}$

reactions of the reagents, hydrolysis reactions of the dissolved components, and chemical reactions of the flotation reagents. The chemical behaviour of the solution dominates the conditions and various balanced relations of these reactions (Ananthapadmanabhan and Somasundaran, 1985). 


\section{Synthesis of 3-hydroxy-2-naphthyl hydroxamic acid collector}

Once the minerals contact water, they will be dissolved. This is relevant to the properties of both the minerals and the solution. The dissolved mineral components will also undergo different chemical reactions to form a variety of chemical components, thereby affecting the surface properties of the minerals (Pugh, 1991).

After bastnaesite has been cracked and dissociated, rare earth cations are exposed on the surfaces of the lattices. Studies have shown that these ions have a relatively high hydration energy and easily undergo hydration in aqueous solutions to form hydroxyl-complex ions with strong surface activities, and can be strongly adsorbed in the compact layer (Stern layer) of the double electrode layer of bastnaesite, which affects the surface zeta potential of bastnaesite (Fuerstenau, 1983). In aqueous solutions, the rare-earth metal cations are hydrolysed. $\mathrm{Ce}^{3+}$ can be taken as an example. Figure 8 shows the hydrolytic equilibrium diagram in the aqueous solution at a $\mathrm{Ce}^{3+}$ concentration of $1 \times 10^{-3}$ $\mathrm{mol} / \mathrm{L}$.

The hydrolysis reaction of $\mathrm{Ce}^{3+}$ in the aqueous solution can be written as follows (Ren et al., 1997):

$$
\begin{aligned}
& \mathrm{Ce}^{3+}+\mathrm{H}_{2} \mathrm{O} \rightarrow \mathrm{Ce}(\mathrm{OH})^{2+}+\mathrm{H}^{+} \quad \mathrm{K}_{1}=10^{5.9} \\
& \mathrm{Ce}(\mathrm{OH})^{2+}+\mathrm{H}_{2} \mathrm{O} \rightarrow \mathrm{Ce}(\mathrm{OH})^{+}{ }_{2}+\mathrm{H}^{+} \mathrm{K}_{2}=10^{5.8} \\
& \mathrm{Ce}(\mathrm{OH})^{+}{ }_{2}+\mathrm{H}_{2} \mathrm{O} \rightarrow \mathrm{Ce}(\mathrm{OH})_{3}+\mathrm{H}^{+} \mathrm{K}_{3}=10^{4.3} \\
& \mathrm{Ce}(\mathrm{OH})_{3}+\mathrm{H}_{2} \mathrm{O} \rightarrow \mathrm{Ce}(\mathrm{OH})_{4}^{-}+\mathrm{H}^{+} \mathrm{K}_{4}=10^{2.0}
\end{aligned}
$$

As shown in Figure 8, different hydrolysis products of the rare earth cations predominate in aqueous solution at different $\mathrm{pH}$ conditions, and their levels of concentration affect the chemical adsorption of the reagents. At $\mathrm{pH}<9$, the dominant hydrolysis components are $\mathrm{Ce}(\mathrm{OH})_{2}{ }^{+}, \mathrm{Ce}(\mathrm{OH})^{2+}$, and $\mathrm{Ce}^{3+}$. At $\mathrm{pH}>9$, the dominant hydrolysis components are $\mathrm{Ce}(\mathrm{OH})_{3}$ and $\mathrm{Ce}(\mathrm{OH})_{4}{ }^{-}$, and the concentrations of $\mathrm{Ce}(\mathrm{OH})^{2+}$ and $\mathrm{Ce}^{3}+$ began to decrease. At $\mathrm{pH} 8-9$, the dominant components are $\mathrm{Ce}(\mathrm{OH})_{2}{ }^{+}$and $\mathrm{Ce}(\mathrm{OH})^{2+}$. This $\mathrm{pH}$ range is also the best for bastnaesite flotation (as shown in Figure 3). Hydroxamic acid anions dissociated from $\mathrm{H} 2 \mathrm{O} 5$ undergo a chemical adsorption reaction with the hydroxy complexes on the surfaces of bastnaesite to form a stable five-membered ring complex, as shown in Figure 9. As a result, bastnaesite became hydrophobic (He and Vaisey, 2012). The $\mathrm{OH}-$ concentration in the pulp gradually increased at $\mathrm{pH}>9$. According to the 'chemical reaction hypothesis' or the 'solubility product hypothesis' proposed by Taggart and

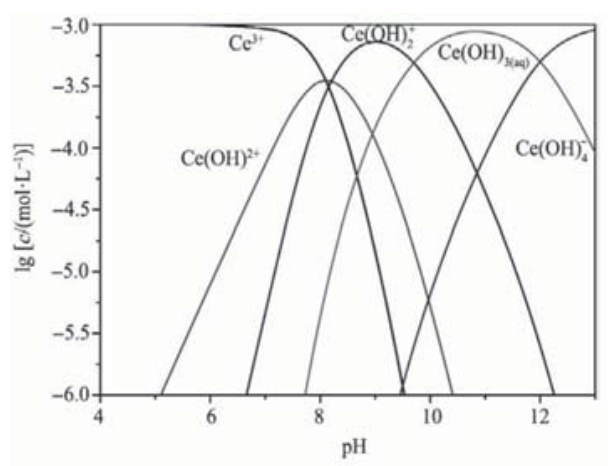

Figure 8-Aqueous solution equilibria for $\mathrm{Ce}^{3+}$ at $10^{-3} \mathrm{~mol} / \mathrm{L}$ total solution concentration (Wang et al., 2014)
Plaksins for flotation reagents $(\mathrm{Hu}, 2014)$, a Ce $(\mathrm{OH})_{3}$ cover film forms on the surfaces of bastnaesite, which prevents the combination of hydroximic acid ions with rare earth ions and reduces the recovery rate of bastnaesite. In an acidic medium $(\mathrm{pH}<7)$, the dominant hydrolysis component of the rare earth ion is $\mathrm{Ce}^{3+}$. Theoretically, hydroximic acid could react with $\mathrm{Ce}^{3+}$ to form the chelate (Liu et al., 1989). However, in this pH range bastnaesite had very poor floatability (as shown in Figure 3), indicating that the dominant hydrolysis component, $\mathrm{Ce}^{3+}$, was unfavourable to flotation. According to the coordinated complexation reaction theory of coordination chemistry (Luo, 2012), as the pH of the flotation pulp is adjusted by addition of hydrochloric acid, $\mathrm{Cl}^{-}$and hydroxamic acid in the pulp are adsorbed onto the surfaces of the minerals competitively to reduce the floatability. Furthermore, because hydroxamic acid is weaker than carbonic acid, when the pH is lowered, fewer hydroxamic acid ions dissociate from the pulp. According to the coordinated complexation reaction theory (Luo, 2012), when the concentration of ionic hydroxamic acid was reduced, the coordination capability with the ions on the bastnaesite surfaces was also lowered. This means that any acidic conditions are unfavourable for bastnaesite floatation.

\section{Zeta potential analysis}

Figure 10 shows the relationship between the zeta potential and $\mathrm{pH}$. The isoelectric point (IEP) of pure bastnaesite was at $\mathrm{pH}$ 8.1. After bastnaesite reacted with $\mathrm{H} 2 \mathrm{O}$, the zeta potential moved in the negative direction and the IEP moved from $\mathrm{pH} 8.1$ to 6.6 , which suggests that $\mathrm{H} 205$ ions were adsorbed on the bastnaesite surfaces. The collector was adsorbed on the mineral surfaces in an ionic form by either chemical adsorption or physical adsorption as a result of electrostatic attraction forces. In the $\mathrm{pH}$ range greater than the IEP, H2O5 could still be adsorbed onto the surfaces of the negatively charged bastnaesite to produce a higher negative potential. Therefore, we can conclude that $\mathrm{H} 2 \mathrm{O} 5$ ions were not electrostatically adsorbed onto the surfaces of the bastnaesite, but entered the compact double-electrode layer of the bastnaesite by chemical adsorption.

Zeta potential that becomes more negative in the presence of a collector is associated with the compositions of both collector and the bastnaesite-water interface at different $\mathrm{pH}$ values. The organic compounds that contain hydroxamic acid groups (-CONHOH) have an affinity for REEs (Zhou, 2015). Since the pKa of H205 is about 7.0 (Che et al., 2004a, 2004 b), the polar group in $\mathrm{H} 205$ registers mainly as neutral hydroxamic acid groups (-CONHOH) at $\mathrm{pH}<7.0$, and the $\mathrm{H} 205$ anion $\left(\mathrm{C}\left(\mathrm{O}^{-}\right) \mathrm{N}\left(\mathrm{O}^{-}\right)\right)$at $\mathrm{pH}>7.0$. When $\mathrm{H} 205$ was introduced into the pulp at different $\mathrm{pH}$ values, its species

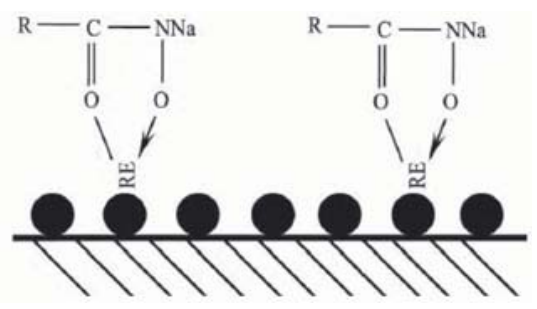

Figure 9-Action mode of $\mathrm{H} 205$ and bastnaesite $\left(\mathbf{R}=\mathcal{O}_{\mathrm{OH}}\right)$ 


\section{Synthesis of 3-hydroxy-2-naphthyl hydroxamic acid collector}

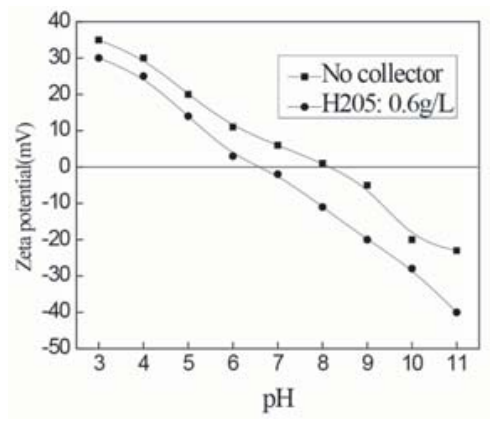

Figure 10-Relationship between zeta potential and pH

with more negative charge possibly replaced $\mathrm{H}_{2} \mathrm{O}, \mathrm{OH}^{-}$, or O2in the bastnaesite/water interface, thus resulting in the zeta potential of the minerals declined (Zhou et al., 2015a, 2015b; Jiang, Li, and Feng, 2011). The IEP of bastnaesite was at $\mathrm{pH}$ 8.0 (as shown in Figure 10). Since both bastnaesite and $\mathrm{H} 205$ are negatively charged at $\mathrm{pH}>8.0$, the adsorption of H205 on the surfaces of bastnaesite has to overcome the electrostatic repulsion. However, H205 could be adsorbed on the bastnaesite surfaces at $\mathrm{pH}>8.0$, so the collection of $\mathrm{H} 205$ to bastnaesite was a result of the chemical adsorption, which formed a five-membered ring chelate. At $\mathrm{pH}<8.0$, because the IEP of bastnaesite in the absence of $\mathrm{H} 205$ was about $\mathrm{pH}$ 8.0. (as shown in Figure 10), bastnaesite is positively charged. H205 may adsorb on the bastnaesite surfaces by physical adsorption or chemical adsorption. The change in zeta potential could reflect the interaction between collector and mineral. In the presence of $\mathrm{H} 205$, the zeta potential of bastnaesite particles became more negative, inferring that H205 can adsorb onto bastnaesite surfaces.

\section{Conclusions}

1. H2O5 has a good collecting property for bastnaesite. The bastnaesite has relatively good floatability in the range of $\mathrm{pH} 7-10$ and the best floatability at approximately $\mathrm{pH} 9$

2. Chemical analysis of the mineral solution showed that the types and concentrations of the hydrolysis products of the rare earth cations on the surfaces of bastnaesite affect the floatability of the minerals. In aqueous solution at $\mathrm{pH}$ 8-9, the major hydrolysis products $\mathrm{RE}(\mathrm{OH})^{2+}$ and $\mathrm{RE}(\mathrm{OH})_{2}{ }^{+}$are the main positive active points and are adsorbed to the surfaces of the bastnaesite. At $\mathrm{pH}<7$, the major hydrolysis product is $\mathrm{RE}_{3}{ }^{+}$, which is unfavourable for collection and considered to be the main negative active point. At $\mathrm{pH}>9$, the major hydrolysis products are $\mathrm{RE}(\mathrm{OH})_{3}$ and $\mathrm{RE}(\mathrm{OH})_{4}^{-}$, which are adsorbed onto the bastnaesite surfaces. This is unfavourable for floatation and is also considered to be a main negative active point

3. Zeta potential analysis indicates that at $\mathrm{pH} 8-9, \mathrm{H} 2 \mathrm{O} 5$ is adsorbed chemically on the surface of the bastnaesite to form stable five-membered ring chelate. At $\mathrm{pH}<8.0$, bastnaesite is positively charged and H205 may adsorb on the mineral surfaces by either physical or chemical adsorption.

4. Surface adsorption measurements indicate that the preferable $\mathrm{pH}$ range for $\mathrm{H} 2 \mathrm{O} 5$ adsorption on bastnaesite surfaces is pH 7-10. $\mathrm{H} 205$ adsorption reaches its maximum value at $\mathrm{pH} 8$.

Bastnaesite is a typical oxidized mineral, which is usually associated with fluorite, apatite, haematite, and quartz. According to our conclusions, $\mathrm{H} 2 \mathrm{O} 5$ has a good collecting property for bastnaesite. The flotation performance of bastnaesite with $\mathrm{H} 2 \mathrm{O} 5$ was best at $\mathrm{pH}$ 8-9. Water glass and sodium carboxymethyl cellulose (CMC) as depressants of gangue minerals (fluorite, apatite, haematite, and quartz), with $\mathrm{H} 2 \mathrm{O} 5$ as collector, are recommended for bastnaesite flotation.

Open- and closed-circuit flotation experiments were carried out under the optimum conditions so as to simulate the industrial flotation process. The factors influencing the flotation process, such as the pulp concentration, mineral particle size, flotation temperature, and H205, depressant, and frother additions, were investigated to establish the optimum flotation conditions.. Preliminary tests covering gravity and magnetic separation were also conducted. Although flotation is the main concentration method for rare earth ores, other unit operations such as magnetic and gravity separation prior to flotation may obtain better results.

\section{Acknowledgments}

The authors acknowledge the support of the Major State Basic Research Development Program of China (973 program) (2012CBA01205).

\section{References}

ABRAHAmI, S.T., XIAO, Y., and YANG, Y. 2015. Rare-earth elements recovery from post-consumer hard-disc drives. Mineral Processing and Extractive Metallurgy, vol. 124, no. 2. pp. 106-115.

ANANTHAPADMANABHAN, K.P. and Somasundaran, P. 1985. Surface precipitation of inorganics and surfactants and its role in adsorption and flotation. Colloids and Surfaces, vol. 13. pp. 151-167.

Buglyo, P., Nagy, E.M., Farkas, E., Sovago, I., Sanna, D., and Micera, G. 2007. New insights into the metal ion-peptide hydroxamate interactions: metal complexes of primary hydroxamic acid derivatives of common dipeptides in aqueous solution. Polyhedron, vol. 26. pp. 1625-1633.

CAI, Z.L., CAO, M.L., CHE, L.P., Yu, Y.F., and Hu, H.Y. 2009. Study on the beneficiation process for recovering rare-earth from the LIMS tailing of HIMS rougher concentrate after magnetizing roasting in Baogang concentrator. Metal Mine, vol. 7. p. 155 (in Chinese).

Chelgani, S., Chehreh A., Rudolph, M.A., Leistner, T.A., and GutZmer, J.A. 2015. A review of rare earth minerals flotation: monazite and xenotime. International Journal of Mining Science and Technology, vol. 25. pp. $877-883$.

Che, L.P., Yu, Y.F., PAng, J.X., Yuan, J.Z., and Zhang, F.G. 2004a. Application and trend of hydroximic acid as collectors on flotation of RE minerals. Chinese Rare Earths, vol. 25, no. 3. pp. 49-54 (in Chinese).

Che, L.P., Yu, Y.F., PAng, J.X., Yuan J.Z., and Wang X.T. 2004b. Synthesis and properties of hydroxamic acid collectors and their mechanism in the flotation of rare earth minerals. Chinese Rare Earths, vol. 25, no. 6. pp. 74-81 (in Chinese). 


\section{Synthesis of 3-hydroxy-2-naphthyl hydroxamic acid collector}

CHEN, Z.H. 2011. Global rare earth resources and scenarios of future rare earth industry. Journal of Rare Earths, vol. 29, no. 1. pp. 1-5.

CHI, R.A. and WANG, D.Z. 2014. Mineral Processing of Rare Earth. 1st edn. Science Press, Beijing, China (in Chinese).

Esquivel, M.R., Bohe, A.E., and Pasquevich, D.M. 2002. Carbochlorination of cerium dioxide. Mineral Processing and Extractive Metallurgy Review, vol. 111 , no. 3. pp. 149-155.

FuERSTENAU, D.W. 1985. Adsorption of hydroxamate collectors on semisoluble minerals. Part II: Effect of temperature on adsorption. Colloids and Surfaces, vol. 15. pp. 137-146.

Fuerstenau, D.W. 1983. The adsorption of hydroxamate on semi-soluble minerals. Part I: Adsorption on barite, calcite and bastnaesite, Colloids and Surfaces, vol. 8. pp. 103-119.

Griffith, D.M., Szocs, B., Keogh, T., Suponitsky, K.Y., Farkas, E., Buglyo, P., and Marmion, C.J. 2011. Suberoylanilide hydroxamic acid, a potent histonedeacetylase inhibitor: its X-ray crystal structure and solid state and solution studies of its $\mathrm{Zn}(\mathrm{II}), \mathrm{Ni}(\mathrm{II}), \mathrm{Cu}$ (II) and $\mathrm{Fe}$ (III) complexes. Journal of Inorganic Biochemistry, vol. 105. pp. 763-769.

HERRERA, R.U. 2003. Recent developments and advances in formulations and applications of chemical reagents used in froth flotation. Mineral Processing and Extractive Metallurgy Review, vol. 24, no. 2. pp. 139-182.

HE, X. J. and VAIseY, M. 2012. Development and research on Mt Weld rare earth ore, Australia. Proceedings of the XXVI International Mineral Processing Congress, New Delhi, India, 23-28 September. Indian Institute of Mineral Engineers. pp. 5860-5890.

Hu, Y.H. 2014. Mineral Flotation. Cha Sha, China (in Chinese).

Jiang, Y., Zhou, L., Zноu, X., and Zнао, B. 2010. Novel condensed ring carboxylic acid studied in the flotation behavior of diaspora and aluminosilicates. Separation Science and Technology, vol. 45. pp. $2475-2480$.

JiAng, Y R., LI, W., and FEnG, R. 2011. Preparation and performance of 4-alkyl4,4- bis(hydroxyl carbamoyl) carboxylic acid for flotation separation of diaspore against aluminosilicates. Minerals Engineering, vol. 24, no. 14 pp. 1571-1579.

Jordens, A., Marion, C., Kuzmina, O., and Waters, K.E. 2014. Surface chemistry considerations in the flotation of bastnasite. Minerals Engineering, vol. 66-68. pp. 119-129.

JoRDENS, A., CHEN, Y.P., and WATERS, K.E. 2013. A review of the beneficiation of rare earth element bearing minerals. Minerals Engineering, vol. 41. pp. $97-114$.

KRISHNAMURTHY, N. and GUPTAC, K. 2002. Rare earth metals and alloys by electrolytic methods. Mineral Processing and Extractive Metallurgy Review, vol. 22, no. 4-6. pp. 477-507.

LEe, J.S., NAgaraJ, D.R., and CoE, J.E. 1998. Practical aspects of oxide copper recovery with alkyl hydroxamates. Minerals Engineering, vol. 11. pp. 929-939.
Liv, G.H., Wu, H.B., Liu, J., SHI, X.G., and Liv, Q.B. 1989. Stability constants of compound of rare earth with hydroxamic acid. Journal of Inorganic Chemistry, vol. 5, no. 2. p. 30 (in Chinese).

Luo, Q.H. 2012. Coordination Chemistry. Science Press, Beijing, China (in Chinese).

Mousumi, G. AND Venugopal, R. 2016. Modeling of flotation process-an overview of different approaches. Mineral Processing and Extractive Metallurgy Review, vol. 37, no. 2. pp. 120-133.

O'Brien, E.C., Le, R.S., Vaillain,J., Fitzgerald, D.J., and Nolan, K.B. 1997. Metal complexes of salicylhydroxamic acid and 0-acetylsalicyl hydroxamic acid. Inorganica Chimica Acta, vol. 266, no, 1. pp. 117-120.

Pugh, R.J. 1991. The interaction of polyethylene oxide non-ionic surfactant layers adsorbed on hydrophobic minerals. International Journal of Mineral Processing, vol. 33, no. 1-4. pp. 307-320.

REN, J., Lu, S., Song, S., and Niu, J. 1997. New collector for rare earth minera flotation. Minerals Engineering, vol. 10. pp. 1395-1404.

Sreenivas, T. and Padmanabhan, N. P. 2002. Surface chemistry and flotation of cassiterite with alkyl hydroxamates. Colloids and Surfaces A, vol. 205, no. 1-2. pp. 47-59.

WANG, C.H., QIU, X.Y., Hu, Z., WANG, T., and Li, H.W. 2014. Flotation mechanism of bastnaesite by salicylhydroxamic acid. Journal of the Chinese Society of Rare Earths, vol. 32, no. 6. pp. 727-733.

WANG, X.M., LiU, J., and MiLleR, J.D. 2008. Adsorption and self-assembly of octyl hydroxamicacid at a fluorite surface as revealed by sum-frequency vibrational spectroscopy. Journal of Colloid and Interface Science, vol. 325 pp. 398-403.

Wu, X.Q. and ZHU, J.G. 2006. Selective flotation of cassiterite with benzohydroxamic acid. Minerals Engineering, vol. 19. pp. 1410-1417.

Xu, H.F., Zhong, H., TAng, Q., Wang, S., Zhao, G., and Liu, G.Y. 2015. A novel collector2-ethyl-2-hexenoic hydroxamic acid: Flotation performance and adsorption mechanism to ilmenite. Applied Surface Science, vol. 353. pp. 882-889.

XIN, Q.Y., PeI, W.W., and Xu, R.Q. 2006. Basic Organic Chemistry. Chemical Industry Press, Beijing, China (in Chinese).

Xu, J.Q., Xu, X.J., and WAng, J.W. 2002. Synthesis of 1-hydroxy-2naphthylhydroximic acid and application to collecting rare earth minerals. Nonferrous Metals, vol. 54, no. 3. pp. 72-73 (in Chinese).

YosRy, A.A. 1990. Extraction and refining of high purity terbium metal from rare earth resources. Mineral Processing and Extractive Metallurgy Review, vol. 7, no. 2. pp. 95-114.

Zhou, F., Yan, C.J., Wang, H.O., Sun, Q., and Wang, O.Y. 2015a. Flotation behavior of four $\mathrm{C} 18$ hydroxamic acids as collectors of rhodochrosite. Minerals Engineering, vol. 78. pp. 15-20.

Zhou, F., WANG, L.X., Xu, Z.H., Liu, O.X., and ChI, R.A. 2015b. Reactive oily bubble technology for flotation of apatite, dolomite and quartz. International Journal of Mineral Processing, vol. 134. pp. 74-81. 